\title{
Finding the Invisible Women: Gender Stereotypes versus Student Interest in Foreign Policy and Security Subfields
}

Renee L. Buhr, University of St. Thomas, St. Paul

Nicholas Sideras, University of Wisconsin Law School, Madison

ABSTRACT Foreign policy and security studies typically are considered male-dominated domains in the discipline of international relations (IR), yet many women work in these policy domains, particularly in the United States. The "invisible women" working in foreign policy often come from fields such as IR, in which gender stereotypes may influence their understanding of the careers available to them. This research project seeks to understand student assumptions about gender roles in IR and the effects of those assumptions. Survey data collected from students in IR courses in 2011 and 2012 reveal that stereotyping of IR subfields is common but that individual students' academic and career interests often diverge from those stereotypes. This finding is relevant not simply because it may explain the presence of women in foreign-policy careers but also because it provides useful pedagogical information for instructors in the IR field.

\begin{abstract}
T n 2000, I began work in the Central Intelligence Agency (CIA) as a nonproliferation analyst. ${ }^{1}$ I encountered women of varying ranks and skill levels at every stage of my recruitment, training, and career trajectory. My recruiter was a woman. interviewed twice at headquarters, both times with female team chiefs. I was placed on a team of 20-plus analysts, evenly composed of men and women. My first mentor was a 65-year-old female veteran of the Clandestine Service turned analyst. My colleagues throughout the Nonproliferation Center were in teams that also were distributed evenly between male and female analysts. Although the majority of workers in support roles were women, there also was a large proportion of women in the analytical ranks, working on interagency committees, writing items for the President's Daily Brief, and serving as managers. The highest ranks had few women, but even this was questioned in 2000 when Director of Central Intelligence George Tenet selected Jami Miscik, a career CIA officer and economic analyst, to serve as Associate Deputy Director of Intelligence. ${ }^{2}$
\end{abstract}

Renee L. Buhr is associate professor in political science at the University of St. Thomas in St.Paul. She can be reached at buhr6782@stthomas.edu.

Nicholas Sideras is Senior Note $\mathcal{E}$ Comment Editor, Wisconsin International Law Journal at the University of Wisconsin Law School in Madison. He can be reached at Sideras@wisc.edu.
Individuals with experience in the US intelligence community may be forgiven if they view my experience as commonplace and perhaps unworthy of retelling. However, as is becoming increasingly clear in popular journals such as Foreign Policy and The Atlantic, the roles played by women in American foreign policy are far from apparent to the academic community or American society in general. ${ }^{3}$ Because employment data at the CIA are classified, it is difficult to obtain official numbers of women and men employed at the agency. Likewise, few women make it "to the top" of the national security apparatus, and individual agencies seldom send their female analysts on the Sunday talk-show circuit. As Hasler (2013) stated, women in intelligence are largely "invisible"; moreover, the "women are tired of being invisible."

Students demonstrate a similar ignorance of these invisible women. In conversations with them, my coauthor and I found a common tendency to assign genders to IR subfields such as security and human rights. Students assume that "boys like guns" and "girls care about people" and that they pursue different subfields as a result. Given my background and interest in encouraging female students to pursue a wide range of careers, I was surprised (and somewhat dismayed) to see gender stereotypes playing such a powerful role. This revelation inspired the research presented in this article. 
Following an approach used by Kenkel and Gage (1983), my coauthor and I answer the following questions: (1) Do students demonstrate a tendency to view certain subfields in terms of gender roles? and (2) Is gender stereotyping reflected in students' own career aspirations? In the process of exploring these questions, a third arose: What does this mean for those of us who teach IR? Do we bore male students when we discuss human rights and development? Do we lose the interest of female students when we focus on "guns and bombs"?

The survey instrument discussed in this article was developed by the coauthors and administered in 2011 and 2012. The data indicate that gender stereotyping of IR subfields among students is common but that individual students often demonstrate academic and career interests that diverge from their own stereotypes. This finding is relevant not simply because it may explain the presence of women in foreign policy and security roles but also because it provides useful pedagogical information for IR instructors.

\section{INTERNATIONAL RELATIONS AND FOREIGN POLICY AS MALE-DOMINATED FIELDS}

The perpetuation of stereotypes may begin in the academy itself. Political science and IR remain male-dominated fields, with women comprising $26 \%$ and $23 \%$, respectively, of faculty teaching in these fields (Maliniak et al. 2008). Recent research
The experience in the classroom is reinforced in the public domain, wherein women who work in foreign-policy positions remain "invisible" primarily because of the barriers that prevent them from reaching the top of their field and being exposed to the larger American public. Explanations are many: legal and normative barriers may explain why women traditionally have played a limited role in foreign affairs (Goldstein 2003; Tickner 2006); and mechanisms of a demand-side (i.e., affecting hiring, evaluation, and promotion) 7 and/or supply-side (i.e., conditioning women to choose gendered fields because they feel more competent in those areas) ${ }^{8}$ nature also may play a role. So-called interactional mechanisms, such as informal face-to-face meetings and "mediated social encounters," may keep women in lower-profile positions in academia or in the foreign-policy workforce. These informal interactions, such as those that occur in a prestigious faculty committee or at foreign-policy-wonk cocktail parties, may have an important role in evaluation and promotion, and research indicates that women are less likely to be in attendance (Brooks 2012; Gorman 2005; Pyke 2011).

In summary, there are a number of forces that lead students to assume that women are scarce in foreign policy. The academic environment, lack of media exposure, and difficulties that constrain women from rising to the top of the US foreign-policy bureaucracies all contribute to the image of foreign policy and security as male domains.

\section{The academic environment, lack of media exposure, and difficulties that constrain women from rising to the top of the US foreign-policy bureaucracies all contribute to the image of foreign policy and security as male domains.}

indicates a division of labor in IR that generally falls along gender-stereotyped lines. Maliniak et al.'s (2008) analysis of the 2006 Teaching, Research, and International Politics Survey data indicates that male professors often teach courses such as American foreign policy, international security, Europe, and North America-domains deemed relevant to great-power politics. Female instructors often teach courses on human rights, transnational actors, international organizations, Latin America, and Africa-regions and topics that often are perceived as peripheral to great-power politics (Maliniak et al. 2008). Explanations for this division of labor (as well as gender differences in tenure and promotion) are numerous and many articles discussing this topic have appeared in this journal alone. ${ }^{4}$ However, regardless of the reason for these differences, one thing is clear: students typically see a man at the front of the room discussing security, whereas they often see a woman discussing human rights. 5

IR has a history of gender stereotyping as well. Gender essentialism has led some researchers to argue that women will be more peaceful, caring, and compromising in their pursuit of foreign-policy objectives (Fukuyama 1998). Scholars have found that these assumptions also can lead some to assume a lower level of foreign-policy competency in women (Charlesworth 2008; Howes and Stevenson 1993; McGlen and Sarkees 1993; Rashotte and Webster 2004; Sanbonmatsu 2003). Despite a wide range of scholarly works that critique these assumptions and find evidence to refute them, ${ }^{6}$ essentialism appears to have some staying power.

\section{SURVEY AND DATA}

A survey was designed to examine the role that gender stereotypes may play in students' interests in IR subfields and careers. The pilot running of the survey took place in 2011 at a private Midwestern university, with subsequent surveys conducted at a public Midwestern university and a private Northeastern liberal arts university in 2012. The classes in which the surveys were conducted included Introduction to International Relations, International Security, American Foreign Policy, and International Law and Organizations. The total number of respondents from the three universities was 224; of these, 121 were male and 103 were female. The distribution of students according to self-identified ideological position was as follows: 58 conservative, 78 liberal, and 71 moderate ( 17 respondents did not answer this question or responded with "other").

Because the survey was intended to gauge actual student interest as well as gendered assumptions, care was taken to avoid "cueing" gender in the initial questions. Respondents were asked to indicate their own areas of interest from a broad list of 22 possible subfields before gender appeared in the survey. Early cues in the survey were crafted to remind the respondents of their status as a student (e.g., respondents were asked the course in which they were enrolled). For similar reasons, demographic questions were posed at the end of the survey.

The IR field was conceived broadly in this survey to capture any perceived gender differences in level of interest in "traditional" subfields (e.g., military policy and international security) and "contemporary" subfields including development, resource 
conflict, and food security. 9 The list of subfields was arranged randomly; security subfields were interspersed with others to decrease the likelihood that respondents would choose their three subfields of interest based on proximity in the list.

Of the 224 respondents, 138 answered "yes" to the question: "In your opinion, are there certain topics in international relations that are of deeper interest to male students than female students, and vice versa?" The students who responded "yes" then were prompted to list three subfields that they consider of particular interest to male and female students. The five most popular responses are listed in table 1.

We wondered if political ideology had an impact on students' perspective regarding gendered subfields. Table 2 lists frequencies of the responses of students who self-identified as liberal, moderate, and conservative to the question addressed in table 1. More than $50 \%$ of respondents in each ideological category answered "yes" to this question, the largest proportion of which was among the self-identified conservatives ( $82 \%)$, followed by liberals (60\%) and moderates (52\%). Moderates had the highest "don't know" response rate at $35 \%$.

Analysis of the data also was aimed toward understanding whether respondents actually follow through on these perceptions rights and ethnic conflict appear near the top of the list in table 3. Foreign policy, international security, international law and organizations, and military policy, however, also appear frequently among the female responses.

Finally, the respondents were asked the following openended question: "If you could choose an international relations field in which to forge a career, which field would it be?" The responses are summarized in table 4 .

When prompted to choose the one field in which they hope to work, the plurality of male and female respondents indicated that their career aspirations are in foreign policy. International law and organizations was also a common response for both male and female students. The large number of female respondents aspiring to a career in human rights fits with the gender stereotypes discussed previously, as does the greater tendency for males to aspire to international security, intelligence, and military-policy-related careers. However, the number and diversity of the areas of career aspiration demonstrated by both males and females in table 4 indicate that in a given IR course, there likely are females who aspire to traditionally male-dominated careers and a number of males who aspire to work in the more stereotypically female-dominated fields.

\section{One option that may prove helpful in the classroom is to work on gender balance in assigned readings, specifically those in the male-stereotyped fields that are written by women and}

vice versa.

of gendered subfields in their own areas of academic interest and career aspirations. Respondents were asked to list the "three topics [from a list of 22 subfields] that you personally find most interesting." Table 3 includes the top 12 subfields most frequently listed in the top three, by male and female respondents. The male respondents' top choices certainly match the expectations listed in table 1 and the female respondents' responses demonstrating interest in human rights match the student beliefs about gendered subfields; however, the other subfields on the two lists are similar across respondents of different sexes.

As shown in table 3, many of the male students indicated an interest in human rights, a purported female stronghold. They likewise demonstrated interest in ethnic conflict, international law and organizations, and international political-economy fields, providing more variety than the security focus attributed to them in table 1 . Of the purportedly female subfields in table 1 , human

Table 1

Top Five Gender-Stereotyped Subfields

\begin{tabular}{ll}
$\begin{array}{l}\text { Greater Interest to Male Students } \\
\text { (frequency of response) }\end{array}$ & $\begin{array}{c}\text { Greater Interest to Female Students } \\
\text { (frequency of response) }\end{array}$ \\
\hline Military policy (117) & Women's studies (95) \\
\hline Weapons (93) & Human rights (71) \\
\hline International security (35) & Child soldiers (28) \\
\hline Diplomatic history (13) & Public health (25) \\
\hline Foreign policy (13) & Ethnic conflict (22) \\
\hline
\end{tabular}

\section{RECOMMENDATIONS}

It appears that gender stereotypes are alive and well in the IR field. Although students' actual interests diverge from the stereotype, they nevertheless provide a predictable list of subfields that they attribute to males and females. However, in the case of the students surveyed in this study, they do not tend to follow their own gender assumptions when considering their own academic and career interests. For the female respondents in particular, more "masculine" fields such as international security and foreign policy often made an appearance on the lists of their favorite topics, and their most frequently cited "dream job" was in the foreign-affairs field. Although the small sample size suggests caution in interpreting the data as representative of all students in IR courses, the data show clear trends that are worth considering.

What does this mean for us, as teachers of IR courses? First, we must be aware of the lingering gender stereotypes in the field in our roles as teachers, advisors, and mentors. Instructors must

Table 2

Political Ideology and Perception of Gendered Subfields

\begin{tabular}{lccc} 
Ideology & Yes & No & Don't Know \\
\hline Liberal & $45(60 \%)$ & $16(21 \%)$ & $14(18 \%)$ \\
\hline Moderate & $37(52 \%)$ & $9(12 \%)$ & $25(35 \%)$ \\
\hline Conservative & $48(82 \%)$ & $6(10 \%)$ & $4(7 \%)$ \\
\hline
\end{tabular}




\section{Table 3 \\ Top 12 Subfields of Personal Interest to Respondents}

\begin{tabular}{ll} 
Males (times mentioned) & \multicolumn{1}{c}{ Females (times mentioned) } \\
\hline International security (44) & Human rights (56) \\
\hline Military policy (42) & Foreign policy (34) \\
\hline Foreign policy (36) & Ethnic conflict (26) \\
\hline Weapons (36) & International law and organizations (26) \\
\hline Human rights (26) & International security (24) \\
\hline Ethnic conflict (23) & Geographical area studies (19) \\
\hline $\begin{array}{l}\text { International law and } \\
\text { organizations (20) }\end{array}$ & Military policy (15) \\
\hline $\begin{array}{l}\text { International political } \\
\text { economy (19) }\end{array}$ & Women's studies (15) \\
\hline $\begin{array}{l}\text { Diplomatic history (18) } \\
\text { IR theory (14) }\end{array}$ & Dispute resolution (12) \\
\hline Globalization (14) & Justice and peace studies (11) \\
\hline $\begin{array}{l}\text { Geographical area } \\
\text { studies (13) }\end{array}$ & Globalization (10) \\
\hline
\end{tabular}

support students in pursuing their genuine interests in multiple ways. Bringing students into one-on-one discussions about their academic and career interests is one place to begin, with a focus on providing information about programs and careers that are relevant to their particular interests. Also, the simple act of reassuring students of the legitimacy of their pursuit of a field

Table 4

\section{Career Aspirations}

\begin{tabular}{ll} 
Males (times mentioned) & \multicolumn{1}{c}{ Females (times mentioned) } \\
\hline $\begin{array}{l}\text { Foreign policy (18) } \\
\begin{array}{l}\text { International law and } \\
\text { organizations (14) }\end{array}\end{array}$ & Foreign policy (18) \\
\hline International security (11) & $\begin{array}{l}\text { International law and } \\
\text { organizations (8) }\end{array}$ \\
\hline $\begin{array}{l}\text { International political } \\
\text { economy (10) }\end{array}$ & Public health (6) \\
\hline Military policy (9) & Environmental studies (5) \\
\hline Intelligence (8) & Justice and peace studies (5) \\
\hline Human rights (4) & Development studies (4) \\
\hline Geographical area studies (3) & Geographical area studies (4) \\
\hline Development studies (3) & Military policy (4) \\
\hline Environmental studies (3) & Intelligence (3) \\
\hline Dispute resolution (2) & International political economy (3) \\
\hline Justice and peace studies (2) & International security (3) \\
\hline Ethnic conflict (1) & Dispute resolution (2) \\
\hline Food security (1) & Ethnic conflict (2) \\
\hline Public health (1) & Weapons (1) \\
\hline Weapons (1) & \\
\hline
\end{tabular}

that deviates from their gender stereotype can be useful; referring them to a relevant role model or academic and/or professional contact may enforce that legitimacy. For example, a female student with interests in intelligence could be introduced to the $\mathrm{HBO}$ documentary Manhunt, which includes extensive interviews with women in that field. Likewise, connecting a student with former students working in the field (e.g., using a Facebook alumni page) can be beneficial in multiple ways.

One option that may prove helpful in the classroom is to work on gender balance in assigned readings, specifically those in the male-stereotyped fields that are written by women and vice versa. Gender assumptions can be brought up during class by explicitly noting the gender of the writer and how that author fits into the overall academic discussion of the topic. Although this effort would take little class time, it would change the students' understanding of the authors they are reading from a simple, non-gendered surname typically used in discussion to a person with a first name and assumed gender.

The data also suggest that we can benefit the widest range of male and female students if we mainstream gender into IR courses. As Cassese, Bos, and Duncan (2012) suggest, this would call for "infusing" gender into typical IR courses. Such an approach is both useful and reflective of post-Cold War trends in the IR field. For example, an international-security course that takes a contemporary approach inclusive of both "guns and bombs" and contemporary topics such as ethnic conflict, natural-resource scarcity, and human security is likely to entail the roles of women and gender. Likewise, an international-political-economy course that covers development and microfinance provides opportunities to "see women" in the coursework. This, in turn, could attract and retain more women in the political-science and IR fields and may increase the number of women pursuing graduate degrees and careers in those fields (Cassese, Bos, and Duncan 2012). It also appears that a number of male students may be interested in these contemporary topics. Therefore, even in courses that are heavily skewed in enrollment-such as internationalsecurity courses that typically enroll mostly male students-an instructor can construct a course that broadly covers the topic. This provides reassurance that contemporary topics likely will be viewed favorably by a number of students in the class-and, in fact, also may reach a few "invisible men."

\section{ACKNOWLEDGMENTS}

The authors thank Alice Kang and two anonymous reviewers for their suggestions on a previous draft of this article, as well as Amy Forster-Rothbart, Patrice McMahon, Courtney Hillebrecht, and Ross Miller for their assistance in administering the surveys. We also thank Alexandra Kraemer for her assistance in coding the data. This research project was partially supported by a Partnership in Learning Grant from the University of St. Thomas.

\section{NOTES}

1. The biographical information in this paragraph refers to the first author, Renee L. Buhr.

2. “DCI Names Deputy Director for Intelligence." Central Intelligence Agency press release, August 18, 2000. Available at www.cia.gov/news-information/ press-releases-statements/press-release-archive-200o/pro818200o.html. Accessed on November 5, 2013.

3. For example, see Brooks (2012) and Slaughter (2012).

4. For example, see McLaughlin Mitchell and Hesli (2013) and Pyke (2011). See also Maliniak et al. (2008) and McMurtie (2013). 
5. Naturally, these numbers are not absolute and exceptions exist. Nevertheless, this gendered division of labor found in many universities may send signals to students that these subfields are gendered.

6. Some examples of work refuting essentialism include Holsti and Rosenau (1981), Howes and Stevenson (1993), and McGlen and Sarkees (1993), and work that provides empirical evidence that women in foreign-policy positions behave and even think in ways similar to men, whereas Ehrenreich (1999) took issue with gender-essentialist assumptions that males are inherently more violent.

7. For example, see Charles (2003), Kenkel and Gage (1983), Naffzinger and Naffzinger (1974).

8. For example, see Correll (2004) and Kenkel and Gage (1983).

9. By "traditional," we mean subfields that commonly were taught during the Cold War era, whereas "contemporary" subfields are those that have gained more policy and research attention in the post-Cold War era.

\section{REF E RE N C ES}

Brooks, Rosa. 2012. "You Can Have It All...Once Your Kids Are in College." Foreign Policy Magazine. November 29. Available at www.foreignpolicy.com/ articles/2012/11/29/you_can_have_it_all_once_your_kids_are_in_college. Accessed August 2, 2013.

Cassese, Erin, Angela Bos, and Lauren Duncan. 2012. "Integrating Gender into the Political Science Core Curriculum." PS: Political Science and Politics 46 (2): 238-43.

Charles, Maria. 2003. "Deciphering Sex Segregation: Vertical and Horizontal Inequalities in Ten National Labor Markets." Acta Sociologica 46 (4): 267-87.

Charlesworth, Hilary. 2008. "Are Women Peaceful? Reflections on the Role of Women in Peace-Building." Feminist Legal Studies 16: 347-61.

Correll, Shelley. 2004. "Constraints into Preferences: Gender, Status, and Emerging Career Aspirations." American Sociological Review 69 (1): 93-113.

Ehrenreich, Barbara. 1999. "Men Hate War Too." Foreign Affairs 78 (1): 118-22.

Fukuyama, Francis. 1998. "Women and the Evolution of World Politics." Foreign Affairs 77 (5): 24-40.

Goldstein, Joshua S. 2003. War and Gender: How Gender Shapes the War System and Vice Versa. Cambridge: Cambridge University Press.
Gorman, Elizabeth. 2005. "Gender Stereotypes, Same-Gender Preferences, and Organizational Variation in the Hiring of Women: Evidence from Law Firms.' American Sociological Review 70 (4): 702-28.

Hasler, Susan. 2013. "The Invisible Women Who Hunt Terrorists.” CNN. May 3 Available atwww.cnn.com/2013/05/o3/opinion/hasler-women-intelligenceanalysts/index.html. Accessed July 20, 2013.

Holsti, Ole, and James Rosenau. 1981. "The Foreign Policy Beliefs of Women in Leadership Positions." Journal of Politics 43 (2): 326-47.

Howes, Ruth, and Michael Stevenson. 1993. Women and the Use of Military Force. Boulder, CO: Lynne Rienner Publishers.

Kenkel, William, and Bruce Gage. 1983. "The Restricted and Gender-Typed Occupational Aspirations of Young Women: Can They Be Modified?" Family Relations 32 (1): 129-38.

Maliniak, Daniel, Amy Oakes, Susan Peterson, and Michael Tierney. 2008. "Women in International Relations." Politics \& Gender 4 (1): 122-44

McGlen, Nancy, and Meredith Reid Sarkees. 1993. Women in Foreign Policy: The Insiders. New York: Routledge, Chapman and Hall, Inc.

McLaughlin Mitchell, Sara, and Vicki Hesli. 2013. "Women Don't Ask? Women Don't Say No? Bargaining and Service in the Political Science Profession." PS: Political Science and Politics 46 (2): 355-69.

McMurtie, Beth. 2013. "Political Science Is Rife with Gender Bias." The Chronicle of Higher Education. August 30. Available at http://chronicle.com/article/PoliticalScience-Is-Rife-With/141319. Accessed September 10, 2013.

Naffzinger, Claudeen Cline, and Ken Naffzinger. 1974. "Development of Sex Role Stereotypes." The Family Coordinator 23 (3): 251-9.

Pyke, Karen. 2011. "Service and Gender Inequity among Faculty." PS: Political Science and Politics 44 (1): 85-7.

Rashotte, Lisa Slattery, and Murray Webster, Jr. 2004. "Gender Status Beliefs." Social Science Research 34: 618-33

Sanbonmatsu, Kira. 2003. "Political Knowledge and Gender Stereotypes." American Politics Research 31 (6): 575-94.

Slaughter, Anne-Marie. 2012. "Why Women Still Can't Have It All." The Atlantic. June 13. Available at www.theatlantic.com/magazine/archive/2012/07/whywomen-still-cant-have-it-all/309020. Accessed August 2, 2013.

Tickner, J. Ann. 2006. “Feminist Perspectives on International Relations.” In Handbook of International Relations, ed. Walter Carlsnaes, Thomas Risse-Kappen, and Beth A. Simmons, 275-91. London: Sage Publications. 